\title{
AGO1 wt Allele
}

National Cancer Institute

\section{Source}

National Cancer Institute. AGO1 wt Allele. NCI Thesaurus. Code C84487.

Human AGO1 wild-type allele is located in the vicinity of 1 p34.3 and is approximately $61 \mathrm{~kb}$ in length. This allele, which encodes protein argonaute-1, plays a role in the modulation of RNA-mediated gene silencing. 